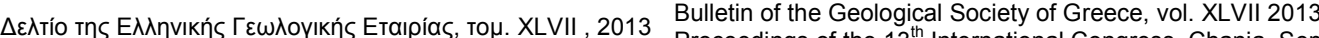
Proceedings of the $13^{\text {th }}$ International Congress, Chania, Sept.

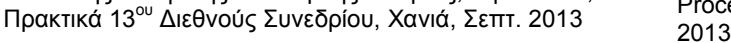

\title{
SUITABILITY ASSESSMENT OF CARBONATE ROCKS FROM THE KATARAKTIS PASSAGE MEMBER OF THE OLONOS - PINDOS ZONE (ILEIA PREFECTURE, WESTERN GREECE) FOR INDUSTRIAL APPLICATIONS
}

\section{Tseni X. ${ }^{1}$, Tsikouras B. ${ }^{1,2}$ and Hatzipanagiotou K. ${ }^{1}$}

${ }^{1}$ University of Patras, Department of Geology, Section of Earth Materials, 26500 Patras, Greece, tseni@upatras.gr,v.tsikouras@upatras.gr,k.hatzipanagiotou@upatras.gr

${ }^{2}$ University of Brunei Darussalam, Department of Petroleum Geosciences, Jalan Tungku Link, Gadong BE1410, Bandar Seri Begawan, Brunei Darussalam

\begin{abstract}
The potential industrial uses of Maastrictian-Paleocene carbonate rocks from the Kataraktis Passage Member of Olonos-Pindos Zone from Ileia Prefecture are evaluated based on their petrographic and geochemical characteristics, as well as their physical properties. Moreover, inter-relationships of the physical properties and geochemical composition were detrmined using simple linear regression analysis, in order to establish their mutual interactions. Investigation of the petrographic and geochemical characteristics of carbonate rocks may contribute to their quality assessment for their use in industrial applications.
\end{abstract}

Key Words: Limestone, Physical properties, Peloponnesus.

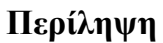

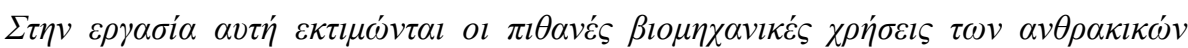

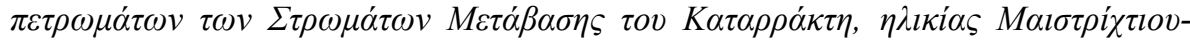

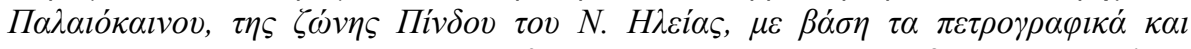

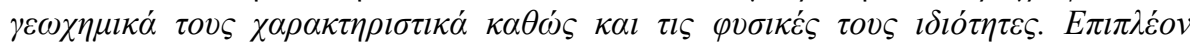

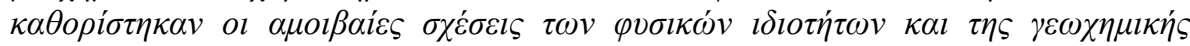

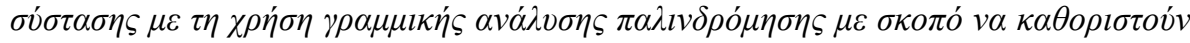

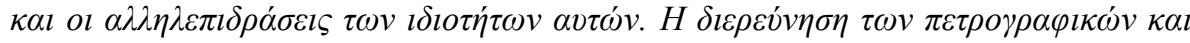

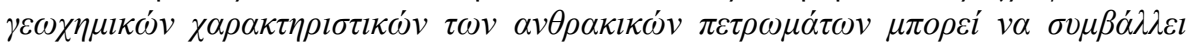

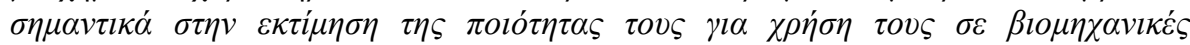
$\varepsilon \varphi \alpha \rho \mu о \gamma \varepsilon ́ \varsigma$.

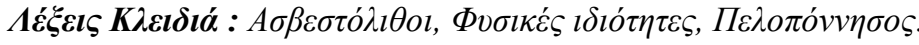

\section{Introduction}

Limestones are industrial rocks mainly used as construction, concrete and road aggregates, as well as dimension stones and fillers. Ground limestone is widely used to raise the $\mathrm{pH}$ of acid soils and as additive in fertilizers. Large amounts of limestone are used in blast furnaces as slag conditioners and in the steel production to form slag. Physical and geotechnical properties of Cretaceous and Maastrictian-Paleocene limestones from different localities have been studied by several authors (Spyropoulos, 2007; Sabatakakis et al., 2008; Mpalatsas et al., 2010; Koulouris, 2011; Tseni et al., 
2012). Mineral and geochemical composition, grain size microstructure, grain packing and porosity are the most important parameters that influence their petrophysical properties.

This paper aims at investigating the physical properties of Maastrictian-Paleocene carbonate samples from the Pindos Zone of Ileia Prefecture, in order to establish their inter-relationships, to study the relationships of physical properties with their petrographic and diagenetic characteristics and to evaluate their suitability as industrial rocks in various applications.

\section{Geological Setting}

The geological setting of the Ileia Prefecture, west Peloponnesus, is characterized by the presence of the Ionian, the Gavrovo-Tripolitza and the Olonos-Pindos geotectonic Zones. The sedimentary rocks of the Pindos Zone (Figure 1) originate from an elongated, remnant ocean basin that formed during mid-Triassic, consisting typically of deep-water carbonate, siliciclastic and siliceous rocks, ranging in age from Late Triassic to Eocene, covered by thick detrital, late Paleocene to Oligocene flysch sediments (Fleury, 1980; Robertson et al., 1991; Robertson, 1994; Degnan and Robertson, 1998, 2006).

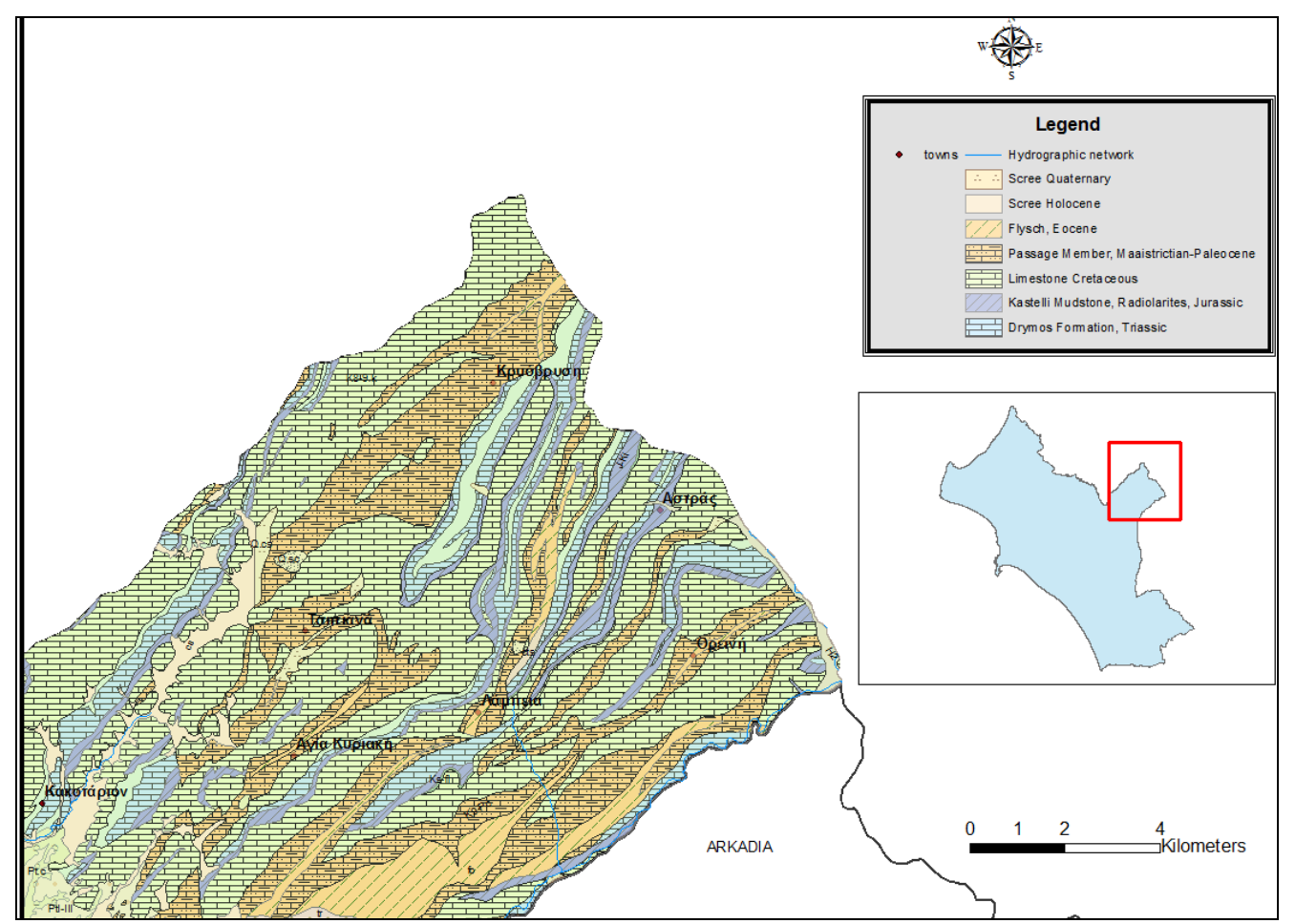

Figure 1 - Geological map of eastern Ileia Prefecture (after IGME, 1978; 1987).

The lower stratigraphic unit in the Pindos Zone is the Priolithos formation of Karnian age comprising medium-grained sandstone with mudstone intercalations (Figure 2). Overlying to the Priolithos formation is the Drimos formation composed of turbiditic and hemipelagic limestone. The Lestenna formation overlies the Drimos formation comprising, from bottom to top, the Kastelli mudstone member, mainly composed of multicolored mudstone, the Aroania member, consisting of Jurassic radiolarites and the first flysch, which includes pelites, limestone, sandstone and red mudstone. Subsequently, Lower Cretaceous to Maastrichtian, redeposited limestone and pelagic limestone were formed. The Kataraktis Passage member of Maastrichtian to Paleocene age overlies this formation, comprising the transition from carbonate to detrital sedimentation. It is 
preserved as thrust imbricated slices (Degnan and Robertson, 1998) and includes pure limestone deposition at its base, comprising the investigated rocks, with increasing clastic input towards the top. The increased input of terrigenous clastic sediments to the basin during Late CretaceousPaleocene suggests that relative sea-level fell because of the erosion to the continental basement to the west and north. The member is dated as Mastrichtian-Paleocene and is marked by the disappearance of Globotruncana sp. and Globorotalia sp. (Degnan, 1998). Finally, the Late Palaeocene-Early Eocene Pindos flysch lies at the top of the pile, likely extending also to MidEocene age in the SE Peloponnesus (Piper, 2006).

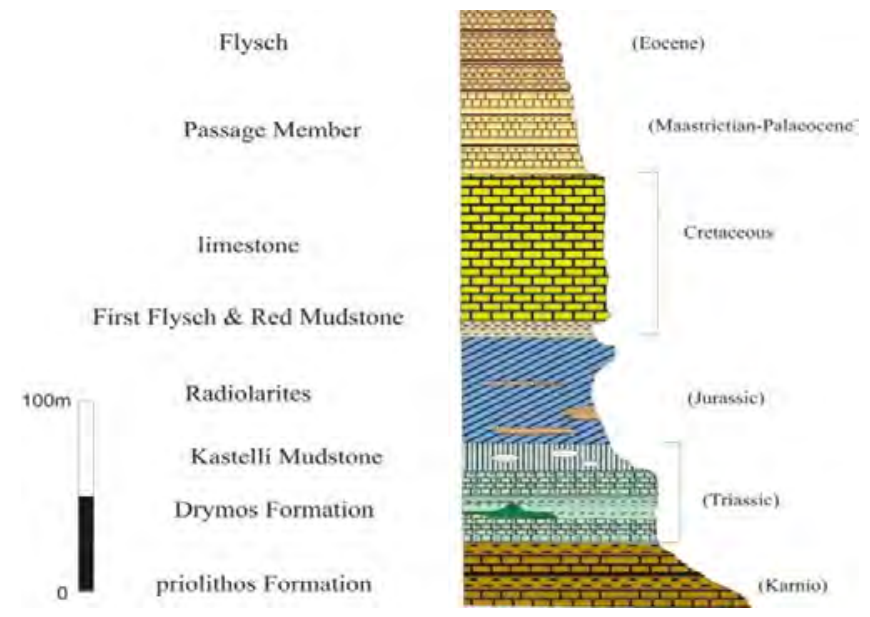

Figure 2 - Simplified stratigraphic section of the Pindos zone at Ileia Prefecture.

\section{Analytical Methods}

Determination of physical properties of the limestones was conducted in the Research Laboratory of Minerals and Rocks, Department of Geology, University of Patras. The insoluble residue was determined after digestion in 25 vol.\% acetic acid (Hirst and Nicholls, 1958). The organic carbon content was determined with titration according to Walkley and Black (1934).

A Hunter color measuring system (Hunter Color Diff. Meter, Miniscan XE plus, Hunter Associates Laboratory Inc., Reston, VA) was used to measure the color. Individual corms were cut transversely and each sample was measured twice for color values. The information given by $\mathrm{L}^{*}$, $\mathrm{a}^{*}$, and $\mathrm{b}^{*}$ is generally expressed as the total color, with $\mathrm{L}^{*}$ representing the brightness or dullness, $\mathrm{a}^{*}$ for redness to greenness, and $\mathrm{b}^{*}$ for yellowness to blueness. The color properties of the carbonate powder were measured according to the CIELAB system using a Diffusion Systems. The source UV content is nominal match to D65 with port diameters $45 / 0$.

The physical properties investigated included moisture content (ASTM D2216), water absorption (ASTM C97-47), bulk specific gravity (AASHTO TIOO-T85) and apparent specific gravity (AASHTO T147). Three tests were performed for each property and the mean values were recorded. Porosity values ( $\mathrm{n} \%$ ) were calculated on rock powders using a pycnometer, according to the ISRM (1981) specification. The total volume of pores is calculated as the difference between the volume of the specimen and that of the powdered particles. Whole rock chemical analyses were performed at Activation Laboratories LTD, Ancaster, Ontario, by fusion ICP-OES for major elements and combined ICP-MS and INAA for trace elements. Detection limit for major elements is $0.01 \%$, except for $\mathrm{TiO}_{2}$ which is $0.005 \%$. Replicate analyses suggest precision better than $5 \%$ for major elements and most trace elements. The determination of $\mathrm{CO}_{2}$ was carried out by coulometry. 


\section{Results}

\subsection{Petrographic Characteristics}

Petrographic study was perfomed on twenty thin sections, which were classified according to the schemes of Dunham (1962) and Folk $(1959,1962)$. Allochems are represented by fossil remains, intraclasts and lithoclasts.

Mudstones with bioclasts or fossiliferous micrites contain micritic calcite with few skeletal grains $(5-15 \%)$ represented principally by pelagic foraminifera. Wackestones with pelagic foraminifers or packed biomicrites are also composed predominately of micritic matrix that supports packed distributed bioclasts (Figure 3a). The petrographic investigation reveals different types of porosity (after Choquette and Pray, 1970; Scholle and Ulmer-Scholle, 2003 ), which are represented by vug and intraparticle porosity (Figure $3 \mathrm{~b}$ ) along with irregular microchannels of stylolites, which are often associated with insoluble residue (mainly clay minerals), accumulated as a consequence of pressure-induced dissolution. Laminated wackestone-packstone include pelagic foraminifera, ranging in size from $50-250 \mu \mathrm{m}$. The lamination comprises skeletal grains such as pelagic foraminifera (Figure 3c) and bioclast in size of fine sand and some lithoclast such as detrital grains of quartz, chlorite and muscovite (Figure 3c, d). Calcite veins and stylolites occur, too.
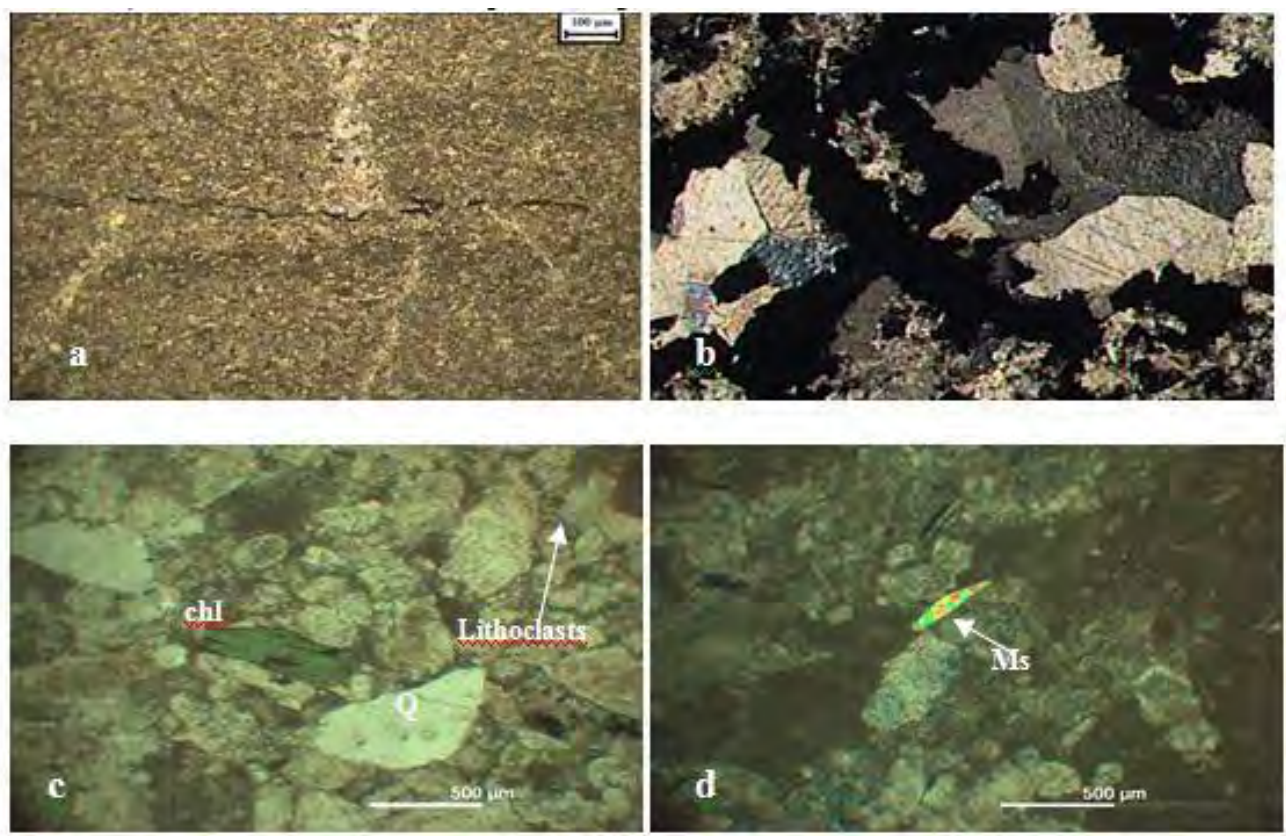

Figure 3 - Photomicrographs of representative carbonate samples from the Kataraktis

Passage Member: (a) wackestone with packed bioclasts; calcite veins and a stylolite filled with clay minerals are also present (sample DHL7G, plane polarized light); (b) vug porosity filled with sparry calcite (sample DHL7A, crossed polarized light); (c, d) laminated wackestone-packstone with pelagic foraminifers and detrital grains of quartz $(Q)$ and chlorite (chl) and muscovite (Ms) (sample DHL16B, crossed polarized light).

\subsection{Physical Properties}

The results of physical and physicochemical properties of the studied samples were determined from the mean values of three measurements and are listed in Table 1. Moisture contents of the Maastrictian-Paleocene carbonates are rather low (0.06-0.07\%), whereas their water absorption values range between 0.05-0.57. These values are lower than the underlying Cretaceous limestone from the Pindos Zone in the Ileia Prefecture (Tseni et al., 2012). Density is one of the most 


\begin{tabular}{|c|c|c|c|c|c|c|c|c|c|c|c|c|c|}
\hline & & $\tilde{\Sigma}$ & oे & $\hat{\tilde{o}}$ & $\begin{array}{l}\stackrel{0}{0} \\
\stackrel{0}{0}\end{array}$ & $\begin{array}{l}\tilde{c} \\
\tilde{o} \\
0 \\
0\end{array}$ & $\begin{array}{l}\text { o } \\
\stackrel{+}{0} \\
0\end{array}$ & ț & $\underset{n}{n}$ & $\tilde{\tilde{o}}$ & $\stackrel{\circ}{\circ}$ & ठิ & 㕝 \\
\hline & & $\mid$\begin{tabular}{|}
0 \\
5 \\
$\vdots$ \\
$\vdots$ \\
-5
\end{tabular} & $\mid$ & $\stackrel{1}{ \pm} \stackrel{\infty}{0}$ & 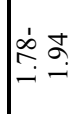 & 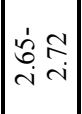 & $\begin{array}{l}\dot{d} \\
\dot{d} \\
\dot{i} \\
i\end{array}$ & $\mid \begin{array}{rr}1 & 0 \\
0 & \stackrel{2}{i} \\
i & \stackrel{i}{c}\end{array}$ & 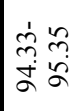 & 我 & $\begin{array}{l}\hat{r}^{2} \\
\sigma^{2} \\
\dot{m}\end{array}$ & $\begin{array}{l}1 \\
0 \\
0 \\
0\end{array}$ & 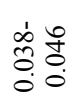 \\
\hline $\mathbb{2}$ & $\begin{array}{l}0 \\
0 \\
0 \\
0 \\
\tilde{\pi} \\
3\end{array}$ & $\Xi$ & : & $\stackrel{8}{\circ}$ & 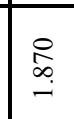 & $\begin{array}{l}\stackrel{0}{\mathscr{D}} \\
\underset{i}{0}\end{array}$ & 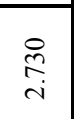 & $\begin{array}{l}0 \\
\stackrel{0}{6} \\
0\end{array}$ & 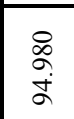 & @্ণী & $\begin{array}{l}\stackrel{P}{\alpha} \\
\dot{m}\end{array}$ & $\stackrel{\circ}{\circ}$ & $\stackrel{0}{\stackrel{0}{0}}$ \\
\hline & & $\tilde{s}$ & $\stackrel{\text { ŏ }}{\circ}$ & di & $\begin{array}{l}\infty \\
\stackrel{0}{0} \\
\stackrel{0}{0}\end{array}$ & $\begin{array}{l}\text { t. } \\
\stackrel{0}{\circ} \\
0\end{array}$ & $\begin{array}{l}\tilde{c} \\
\dot{0} \\
\dot{0}\end{array}$ & 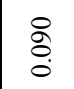 & $\stackrel{n}{=}$ & $\vec{s}$ & $\underset{\hat{\lambda}}{\stackrel{\hat{\sigma}}{0}}$ & 高 & ? \\
\hline & & $\mid$\begin{tabular}{|c|} 
\\
5 \\
$\vdots$ \\
$\vdots$ \\
0
\end{tabular} & 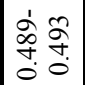 & 守 & $\begin{array}{l}\dot{d} \\
\stackrel{i}{i}\end{array}$ & 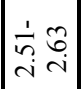 & 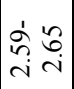 & $\begin{array}{l}1 \\
\dot{\sigma} \\
0 \\
0\end{array}$ & 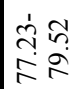 & $\stackrel{m}{\rightarrow} \underset{-}{f}$ & 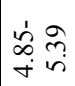 & $\begin{array}{c}\dot{b} \\
\dot{m} \\
\dot{m} \\
\hat{n}\end{array}$ & 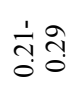 \\
\hline 包 & 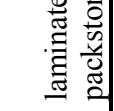 & $\begin{array}{l}\Xi \\
\Xi \\
\Xi\end{array}$ & : & 守 & i̊n. & $\begin{array}{l}\stackrel{8}{n} \\
i \\
i\end{array}$ & $\begin{array}{l}\stackrel{\circ}{0} \\
\stackrel{i}{0}\end{array}$ & $\stackrel{8}{\stackrel{8}{0}}$ & $\begin{array}{l}\stackrel{8}{\circ} \\
\stackrel{\infty}{\circ}\end{array}$ & $\stackrel{\circ}{\stackrel{f}{-}}$ & $\begin{array}{l}\stackrel{0}{0} \\
\stackrel{\circ}{i} \\
i\end{array}$ & : & $\begin{array}{l}\text { ڤે } \\
\text { त̂ } \\
\text { o }\end{array}$ \\
\hline & & $\pi$ & $\stackrel{0}{\circ}$ & 吕 & $\bar{\partial}$ & है. & $\begin{array}{l}\stackrel{0}{0} \\
\stackrel{0}{0}\end{array}$ & 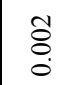 & $\stackrel{\text { ô }}{0}$ & ठ̊. & ठ̊. & $\stackrel{\text { ô }}{0}$ & ठั. \\
\hline & 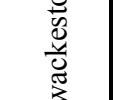 & $\begin{array}{l}\Xi \\
\vdots \\
\Xi\end{array}$ & $\dot{0}$ & 季 & 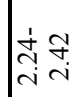 & 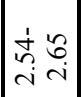 & $\begin{array}{ll}1 & 0 \\
& 0 \\
i & 0\end{array}$ & \begin{tabular}{|l}
1 \\
0 \\
0 \\
0 \\
0
\end{tabular} & 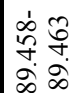 & 它空 & 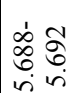 & $\mid \begin{array}{c}1 \\
8 \\
0 \\
i\end{array}$ & 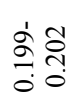 \\
\hline$\exists$ & 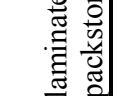 & $\begin{array}{l}\Xi \\
\cong\end{array}$ & : & $\begin{array}{l}0 \\
i \\
0 \\
0\end{array}$ & ల్లై & 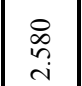 & 导 & 呑 & 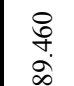 & 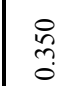 & $\begin{array}{l}\text { \&. } \\
\text { in } \\
\text { in }\end{array}$ & $\stackrel{\stackrel{ }{\vec{i}}}{\text { in }}$ & ્ֻণి \\
\hline & & $\pi$ & $\stackrel{\circ}{\circ}$ & $\overrightarrow{\tilde{o}}$ & $\overrightarrow{\widetilde{\delta}}$ & tै & $\begin{array}{l}2 \\
\tilde{I} \\
0 \\
0\end{array}$ & $\overrightarrow{\tilde{o}}$ & $\stackrel{\vec{m}}{0}$ & $\begin{array}{l}\stackrel{0}{0} \\
\stackrel{0}{0} \\
0\end{array}$ & $\stackrel{\hat{o}}{0}$ & $\begin{array}{l}\stackrel{2}{0} \\
\stackrel{0}{0}\end{array}$ & 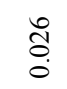 \\
\hline & & $\begin{array}{l}\text { D } \\
\vdots \\
=\end{array}$ & 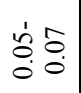 & î: & ồ- & 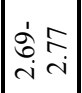 & $\stackrel{\substack{\infty\\
}}{\stackrel{\infty}{i}}$ & 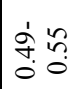 & 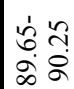 & 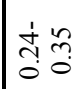 & 究 & 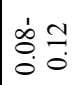 & 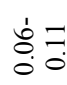 \\
\hline 可 & $\begin{array}{l}\overline{0} \\
\frac{0}{0} \\
\overline{0} \\
3 \\
3\end{array}$ & $\begin{array}{l}\Xi \\
\Xi\end{array}$ & $\stackrel{0}{\circ}$ & : & $\stackrel{8}{\leftrightarrows}$ & 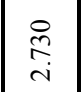 & 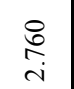 & 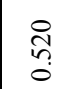 & $\begin{array}{l}\stackrel{8}{\circ} \\
\stackrel{8}{\circ}\end{array}$ & 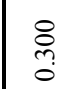 & $\begin{array}{l}\text { ठ̊. } \\
\text { ஸુ }\end{array}$ & $\stackrel{\circ}{\circ}$ & $\begin{array}{l}\stackrel{0}{0} \\
\stackrel{0}{0}\end{array}$ \\
\hline & & $\bar{c}$ & $\stackrel{n}{0}$ & $\begin{array}{l}\overline{\widetilde{\delta}} \\
\dot{0}\end{array}$ & $\stackrel{\substack{0 \\
0}}{0}$ & $\begin{array}{l}n \\
0 \\
0\end{array}$ & $\stackrel{n}{a}$ & 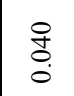 & $\underset{7}{\exists}$ & 峞 & 岂 & $\overrightarrow{\tilde{o}}$ & ஜ̂. \\
\hline & $\Xi$ & 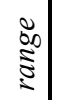 & $\begin{array}{ll}\dot{\delta} & 0 \\
0 & 0 \\
0 & 0\end{array}$ & त่̂ స̃ & 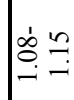 & 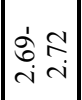 & $\begin{array}{ll}\dot{r} & 0 \\
& \stackrel{i}{i}\end{array}$ & 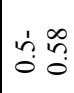 & 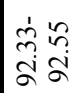 & $\dot{1}=\infty$ & 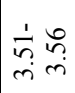 & is & $\begin{array}{l}0 \\
\dot{d} \\
\dot{0}\end{array}=$ \\
\hline 音 & 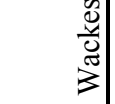 & $\Xi$ & ô. & તิ & $\exists$ & $\stackrel{?}{i}$ & $\stackrel{\stackrel{\hat{i}}{i}}{ }$ & $\hat{n}$ & $\begin{array}{l}\text { İ } \\
\text { ָ̇ }\end{array}$ & $\stackrel{n}{n}$ & $\stackrel{+}{\stackrel{4}{n}}$ & $\stackrel{n}{\circ}$ & $\stackrel{\infty}{\circ}$ \\
\hline 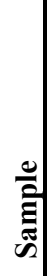 & 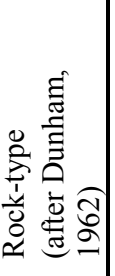 & & 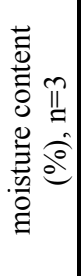 & 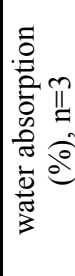 & 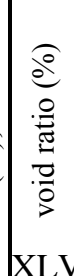 & 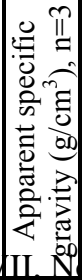 & 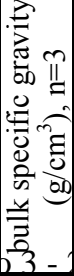 & 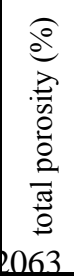 & \lrcorner & * & مُ & 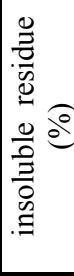 & $\begin{array}{l}\mathbb{\pi} \\
\stackrel{0}{0} \\
0 \\
0 \\
0\end{array}$ \\
\hline
\end{tabular}


important properties of rocks, mainly controlled by their texture and mineral composition. The bulk density depends on petrographic and structural features of the diagenetic processes and geotectonic conditions (Trafimov and Karalov, 1993; Rashed and Sediek, 1997). Bulk specific gravity ranges from 2.61 to $2.76 \mathrm{~g} / \mathrm{cm}^{3}$, in the investigated lithologies. Total porosity, which is an important factor in rock strength since a small change in pore volume can produce appreciable mechanical effect (ISRM, 1981), ranges between 0.52 and $0.70 \%$. Laminated wackestone packstone samples of the formation have higher porosities. The total organic carbon is low ranging from 0.04 to $0.25 \%$, while the insoluble residue shows a wider range of $0.05-3.26 \%$. Samples DHL16A and DHL16B (laminated wackestone-packestone) with the highest total organic carbon and insoluble residue values are found towards upper members, unlike the rest samples that lie at the base of the Kataraktis Passage Member. Moisture content and bulk density are inversely correlated to the insoluble residue (Figure $4 \mathrm{a}, \mathrm{b}$ ), suggesting that clay minerals are not the prevalent water absorbents. The TOC is inversely correlated to the color index $\mathrm{L}$ with the following the empirical equation TOC $=-0.0122 \mathrm{~L}+1.2179$ with a correlation coefficient $\mathrm{R}^{2}=0.75$ (Figure 4c). From Figure $4 \mathrm{~d}$ it is clear that the bulk density of the Kataraktis member limestones decreases with increasing porosity.
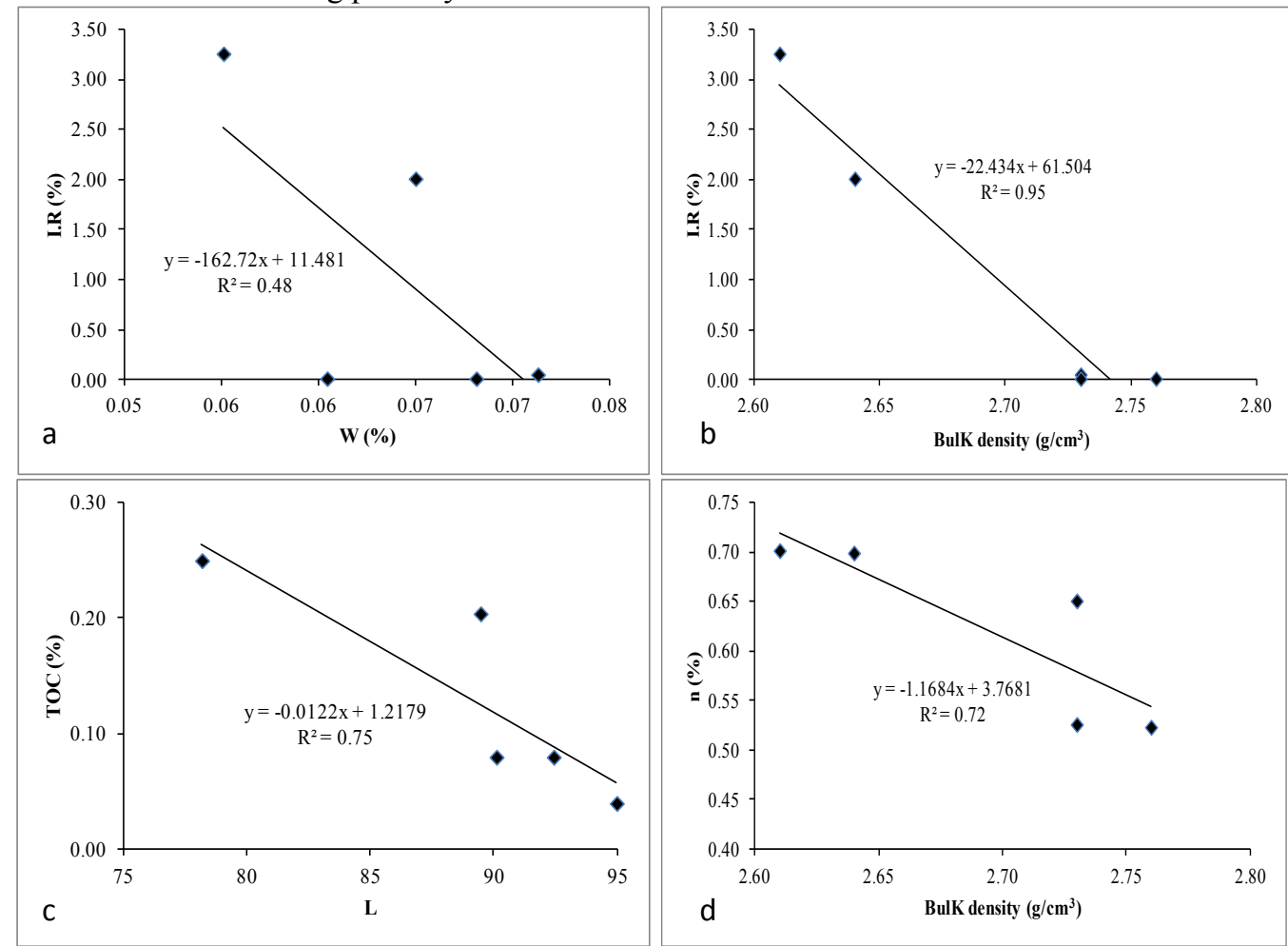

Figure 4 - Correlation diagrams of: a) moisture content (W) with insoluble residue (I.R.); b) bulk density with insoluble residue (I.R.); c) color index L with total organic carbon; d) bulk density with total porosity (n).

\subsection{Geochemical Affinities}

Whole-rock geochemical analyses from representative carbonate rocks are listed in Table 2 . The $\mathrm{CaO}$ contents of the analyzed samples vary between 38.40 and 55.67 wt. \%. According to the chemical classification based on $\mathrm{CaCO}_{3}$ content (Oates, 1998), samples DHL7G and PK1A (wackestone with bioclasts) are calcium limestone of high purity $\left(\mathrm{CaCO}_{3}=97-98.5 \%\right)$ whereas samples DHL7A (mudstone with bioclasts) and DHL16A (laminated wackestone with bioclasts) are median purity limestones $\left(\mathrm{CaCO}_{3}=93.5-97.0 \%\right)$; sample DHL16B is a poor purity limestone 
containing abundant siliciclastic material. The total amount of impurities (sum of all oxides excluding $\mathrm{CaO}$ and $\mathrm{CO}_{2}$ ) for the four samples except DHL16B, is rather low to moderate (Table 2). The concentrations of $\mathrm{MgO}, \mathrm{Fe}_{2} \mathrm{O}_{3}, \mathrm{MnO}$ and $\mathrm{Na}_{2} \mathrm{O}$ are low in the analyzed samples. The low concentration of phosphorus reflects the absence of apatite in the samples (Parekh et al., 1977;

Table 2 - Whole-rock geochemical analyses of representative samples of Cretaceous and Maastrictian-Paleocene limestones from Ileia Perfecture $\left(\mathrm{Fe}_{2} \mathrm{O}_{3}{ }^{\mathrm{t}}\right.$ : total $\mathrm{Fe}$ as $\mathrm{Fe}_{2} \mathrm{O}_{3}$; -: below detection limit).

\begin{tabular}{|c|c|c|c|c|c|}
\hline Sample & DHL7A & DHL7C & DHL16A & DHL16B & PK1A \\
\hline \multicolumn{6}{|c|}{ Major elements (wt. \%) } \\
\hline $\mathrm{SiO}_{2}$ & 1.93 & 1.73 & 1.43 & 20.32 & 0.92 \\
\hline $\mathrm{Al}_{2} \mathrm{O}_{3}$ & 0.32 & 0.21 & 0.33 & 2.95 & 0.18 \\
\hline $\mathrm{Fe}_{2} \mathrm{O}_{3}{ }^{\mathrm{t}}$ & 0.23 & 0.19 & 0.25 & 1.10 & 0.15 \\
\hline MnO & 0.05 & 0.05 & 0.13 & 0.10 & 0.04 \\
\hline MgO & 0.37 & 0.42 & 0.64 & 1.02 & 0.31 \\
\hline $\mathrm{CaO}$ & 54.64 & 55.09 & 54.17 & 38.40 & 55.67 \\
\hline $\mathrm{Na}_{2} \mathrm{O}$ & 0.08 & 0.06 & 0.22 & 0.73 & 0.03 \\
\hline $\mathrm{K}_{2} \mathrm{O}$ & 0.13 & 0.07 & 0.08 & 0.47 & 0.06 \\
\hline $\mathrm{TiO}_{2}$ & 0.01 & 0.01 & 0.01 & 0.19 & 0.00 \\
\hline $\mathbf{P}_{2} \mathbf{O}_{5}$ & 0.01 & 0.01 & 0.09 & 0.06 & 0.02 \\
\hline LOI & 43.20 & 43.13 & 42.74 & 34.72 & 43.14 \\
\hline Total & 101.00 & 101.00 & 100.10 & 100.10 & 100.50 \\
\hline $\mathrm{CaCO}_{3}$ & 96.87 & 97.25 & 96.81 & 73.05 & 98.32 \\
\hline \multicolumn{6}{|c|}{ Trace elements (ppm) } \\
\hline Ag & 0.7 & - & - & - & 0.6 \\
\hline As & - & - & - & 2 & - \\
\hline $\mathbf{B a}$ & 12 & 7 & - & 495 & 6 \\
\hline Co & 6 & 4 & 9 & 19 & 4 \\
\hline $\mathrm{Cr}$ & 5 & 5 & 12 & 124 & 3 \\
\hline Cs & - & - & - & 0.7 & - \\
\hline $\mathbf{C u}$ & 13 & 6 & 6 & 7 & 4 \\
\hline Hf & - & - & - & 1.5 & - \\
\hline $\mathrm{Ni}$ & 7 & 2 & 9 & 40 & 3 \\
\hline $\mathbf{P b}$ & - & - & 9 & 10 & - \\
\hline$S$ & 110 & 150 & 590 & 1010 & 90 \\
\hline Sb & - & - & - & 0.2 & - \\
\hline Sc & 0.4 & 0.4 & 0.6 & 2.9 & 0.4 \\
\hline $\mathrm{Sr}$ & 600 & 508 & 513 & 372 & 671 \\
\hline Th & - & - & - & 1.3 & - \\
\hline $\mathbf{U}$ & - & - & 1.2 & 1.2 & - \\
\hline $\mathbf{V}$ & - & - & 12 & 23 & - \\
\hline W & 10 & 21 & 88 & 186 & 25 \\
\hline $\mathbf{Y}$ & 5 & 4 & 11 & 10 & 2 \\
\hline $\mathrm{Zn}$ & 4 & 5 & 5 & 20 & 4 \\
\hline $\mathbf{Z r}$ & 21 & 12 & 4 & 62 & 15 \\
\hline
\end{tabular}

$\underline{\text { XLVII, No } 3-2065}$ 
Cullers, 2002). Chemical analyses for the amount of trace elements show that only one sample (DHL16B) present higher concentrations of $\mathrm{Cr}$ and Ni compared to the other samples. Sulfur content is fairly coherent displaying inconsiderable variations between 90 and $150 \mathrm{ppm}$ (apart from sample DHL16A with $\mathrm{S}=1010 \mathrm{ppm}$ ). Sr was detected in all samples, however the amount of $\mathrm{Sr}$ in the wackestone with bioclast (PK1A) is higher than the rest samples. Sr is easily mobilized during weathering, especially in oxidizing, acid environments, thus it is incorporated in clay minerals (Kabata-Pendias 2011). Sample DHL16B displays high Ba contents. Ba is also strongly adsorbed by clay minerals and it commonly substitutes for $\mathrm{K}$ in feldspars (Kabata-Pendias 2011). Sample DHL7A demonstrates the highest $\mathrm{Cu}$ values compared to the remaining samples

\section{Discussion-Conclusions}

The Maastrictian-Paleocene carbonate rocks of the Kataraktis Passage Member are divided into 3 microfacies: (i) mudstones with bioclast, (ii) wackestones with bioclast, and (iii) laminated wackestone-packstone. The color index L is negatively correlated with TOC, suggesting that increasing organic components in carbonate rocks have a negative affection on their whiteness, high values of which are commonly desirable in most applications. Organic matter, in carbonate rocks, may shows variable compositions and amounts and may affect their properties. A considerable amount of some impurities may be acceptable in carbonate rocks for some uses, if they are finely disseminated throughout the rocks. On the other hand, if the impurities are concentrated in distinct laminas, they may form planes of weakness that seriously affect the performance of the rocks (Boynton, 1980; Harben, 1992; Carr et al., 1994; Oates, 1998; Christidis et al., 2004).

The $\mathrm{CaCO}_{3}$ content in all analyzed samples exceeds $96.5 \%$, except sample DHL16B with $\mathrm{CaCO}_{3}$ $=76 \%$ (Table 2). The high $\mathrm{SiO}_{2}$ and $\mathrm{Al}_{2} \mathrm{O}_{3}$ contents in sample DHL16B are consistent with the presence of quartz and clay minerals in its insoluble residue. Ba content is low in all samples, except DHL16B with rather high Ba contents (Table 2), likely related to its significant amounts of clay minerals (Kabata-Pendias 2011).

The $\mathrm{CaCO}_{3}$ content in the Maastrictian-Paleocene carbonates from the Kataraktis Passage Member exceeds the limit of $65 \%$. Furthermore their $\mathrm{MgO}$ content is small indicating that these carbonate rocks could be suitable as calciferous raw material for cement production. Also, the insoluble residue, the total organic carbon and the color index, which affect the rock properties, suggest that all samples are suitable for cement production, apart from and the laminated wackestonepackstone of the Maastrictian-Paleocene limestone (sample DHL16B).

All the studied limestones are suitable as $\mathrm{pH}$ regulators in acid soils as well as additives in fertilizers since $\mathrm{CaCO}_{3}$ content exceeds $60 \%$ and their $\mathrm{MgO}$ contents are below 5\%. Finally all examined samples (except the laminated wackestone-packstone sample DHL16B) are suitable for desulphurization of exhaust gases since their $\mathrm{CaCO}_{3}$ contents exceed $95 \%$ while their concentrations in $\mathrm{Al}_{2} \mathrm{O}_{3}(<1 \%), \mathrm{SiO}_{2}(<2 \%)$ and $\mathrm{MgO}(<2 \%)$ are low.

From this study, it is evident that petrographic investigation coupled with mineralogical and geochemical analysis is useful for preliminary assessment of limestones' quality.

\section{Acknowledgments}

The senior author wishes to thank the Greek State Scholarship Foundation (I.K.Y.) for the financial support of this study. Critical review by an anonymous reviewer is gratefully appreciated.

\section{References}

AASHATO T147. The Field Determination of Density of Soil In-Place (1954-70). AASHATO TT85. Specific gravity and absorption of coarse aggregates. 
AMERICAN SOCIETY FOR TESTING AND MATERIALS C97-47. Standard Test methods for Laboratory determination of water absorption.

AMERICAN SOCIETY FOR TESTING AND MATERIALS D2216-10. Standard Test Methods for Laboratory Determination of Water (Moisture) Content of Soil and Rock by Mass.

Boynton S.R. 1980. Chemistry and Technology of Limestone, 2nd edition, New York, Wiley \& Sons, $577 \mathrm{pp}$.

Carr D.D. Rooney L.F. and Freas R.C. 1994. Limestone and dolostone, in: Carr, D.D. (eds), Industrial minerals and rocks: Society for Mining, Metallurgy and Exploration, Littleton, Colorado, $6^{\text {th }}$ Edition, 605-629.

Choquette P.W. and Pray L.C. 1970. Geological nomenclature and classification of porosity in sedimentary carbonates, Bulletin American Association of Petroleum Geologists 54, 207250 .

Christidis G.E., Sakellariou N., Repouskou E. and Markopoulos Th. 2004. Influence of organic matter and iron oxides of the color properties of a micritic limestone from Kefalonia, Bull. Geol. Soc. Greece, 72-79.

Cullers R.L. 2002. Implications of elemental concentrations for provenance, redox conditions and metamorphic studies of shales and limestones near, Chemical Geology 191, 305-327.

Degnan P.J. and Robertson A.H.F. 1998. Mesozoic-early Tertiary passive margin evolution of the Pindos ocean (NW Peloponnese, Greece), Sedimentary Geology 117, 33-70.

Degnan P. J. and Robertson A.H.F. 2006. Synthesis of the tectonic-sedimentary evolution of the Mesozoic-Early Cenozoic Pindos ocean: Evidence from the NW Peloponnese, Greece., in: Robertson, A.H.F., Mountrakis, D., eds.,Tectonic development of the Eastern Mediterranean region, Geological Society London, Special Publications 260, 467-491.

Dunham R.J. 1962. Classification of carbonate rocks according to their depositional texture. In: Ham, W. E., eds., Classification of carbonate rocks: American Association of Petroleum Geologists Memoir 1, 108-121.

Fleury J.J. 1980. Les zones de Gavrovo-Tripolitza et du Pinde-Olonos (Grèce Continental), et Péloponesse du Nord. Evolution d'une plate-forme et d'un bassin dans leur cadre Alpin. Societé de la Géologie de Nord, Lille Publication 4, 1-651.

Folk R.L. 1959. Practical petrographic classification of limestones, Bulletin of American Association of Petroleum Geologists 43, 1-38.

Folk R.L. 1962. Spectral subdivision of limestone types. In: Ham, W. E., eds, Classification of carbonate rocks: American Association of Petroleum Geologists Memoir 1, 62-84.

Harben P.W. 1992. The industrial minerals handybook - A Guide to Markets, Specifications, and Prices, Industrial Minerals Division, Metal Bulletin PLC, United Kingdom 148p.

Hirst D.M. and Nicholls G.D.1958. Techniques in sediment geochemistry-I. Separation of the detrital and non-detrital fractions of limestones. Journal of Sedimentary Petrology 28, 461481.

IGME. 1979. Geological map of Greece, Kertezi sheet, Institute of Geological and Mineral Exploration, Athens

IGME. 1987. Geological map of Greece, Kertezi sheet, Institute of Geological and Mineral Exploration, Athens

ISRM 1981. Rock characterization, testing and monitoring, in: Brown E.T. (eds), ISRM Suggested Methods: International Society for Rock Mechanics, Pergamon Press, London $211 \mathrm{p}$

Kabata-Pendias A., 2011. Trace elements in soils and plants, $4^{\text {th }}$ edition. CRS Press, New York.

Koulouris S., 2011. Strength parameters and rock mechanics of hard soils - soft rocks, Sector of Applied Geology \& Geophysics. Ph.D Thesis, University of Patras, Patras 512 p.

Mpalatsas I., Rigopoulos I., Tsikouras B. and Hatzipanagiotou K. 2010. Suitability assessment of cretaceous limestones from Thermo (Aitolokarnania, western Greece) for their use as base and sub-base aggregates. Bulletin of the Geological Society of Greece, Proceedings of the $12^{\text {th }}$ International Congress Patras, 2010, pp. 2501-2509.

Oates, J.A.H., 1998. Lime and limestone. Chemistry and technology, production and uses, WileyVCH Weinheim, 455 pp. 
Parekh P.P., Moler P., Dulski P. and Basch W.M.1977. Distribution of trace elements between carbonate and non carbonate phases of limestone, Earth and Planetary Science Letters 34, 39-50.

Piper D.J.W. 2006. Sedimentology and tectonic setting of the Pindos Flysch of the Peloponnese, Greece, in: Robertson, A.H.F., Mountrakis, D., eds., Tectonic Development of the Eastern Mediterranean Region: Geological Society, London, Special Publications 260, 493-505.

Robertson A.H.F. 1994. Role of the tectonic facies concept in orogenic analysis and its application to Tethys in the Eastern Mediterranean region, Earth-Science Reviews 37, 139213.

Robertson A.H.F., Clift P.D., Degnan P.J. and Jones G. 1991. Palaeographic and palaeotectonic evolution of the eastern Mediterranean Neotethys, Palaeogeography, Palaeoclimatology, Palaeoecology 87, 289-343.

Rashed M A. and Sediek K. 1997. Petrography, diagenesis and geotechnical properties of the ElRufuf formation (Thebes Group), El-Kharga Oasis, Egypt, Journal of African Earth Sciences, 25,-407-423.

Sabatakakis N., Koukis G., Tsiambaos G. and Papanakli S. 2008. Index properties and strength variation controlled by microstructure for sedimentary rocks, Engineering Geology, 97, 8090.

Scholle P.A. and Ulmer-Scholle Dana S. 2003. A color Guide to the Petrography of Carbonate Rocks: Grains, textures, porosity, diagenesis. AAPG Memoir No. 77, AAPG Publications, Tulsa, OK, 459pp

Spyropoulos A. 2007. Research of the engineering geological conditions of Achaia prefecture in order to find materials suitable for aggregates, Sector of Applied Geology \& Geophysics, Ph.D Thesis, University of Patras, Patras 512 p.

Trafimov V.T. and Karalov B.A. 1993. Practical Soil Sciences in Russian, Moscow State University Publisher, Moscow, 390 pp.

Tseni X., Koutsopoulou E., Tsikouras B. and Hatzipanagiotou K. 2012. Investigation of the mineralogical petrographic, geochemical and physical properties from Ileia Prefecture and assesmnet for industrial applications, Bull. Geol. Soc. Greece, XXXXVI, 105-104

Walkley A. and Black I.A. 1934. An examination of the Degtjareff method for determining organic carbon in soils: Effect of variations in digestion conditions and of inorganic soil constituents, Soil Science 63, 251-263. 